\title{
Assessment of Compliance with OHADA Uniform Accounting Act by Public Limited Companies
}

\author{
Michael Forzeh Fossung ${ }^{1}$ \\ ${ }^{1}$ Department of Accounting and Finance, Faculty of Economics and Management, University of Dschang, Cameroon \\ Correspondence: Michael Forzeh Fossung, P.O.Box 123, Buea Cameroon. E-mail: michael.fossung @ fomicgroup.cm
}

Received: April 27, 2016

Accepted: June 1, 2016

Online Published: June 7, 2016

doi:10.5430/afr.v5n3p1

URL: http://dx.doi.org/10.5430/afr.v5n3p1

\begin{abstract}
Francophone African countries have made a tremendous effort in harmonising domestic standards and reporting with the International Financial Reporting Standards (IFRS). Moving from two distinct OCAM streams to two OHADA streams (effective 1985) and now one OHADA Uniform Accounting Act embodying 17 member countries (effective 2001) is a milestone towards harmonisation of reporting practice both domestically and internationally. This empirical study examines whether the effort of harmonisation, especially after the 2001 standards has resulted in the successful convergence of firms' accounting practices by analysing public limited liability companies' compliance with the OHADA Uniform Accounting Act and if such compliance has improved over time. The study has been carried out using the 2008 and 2009 annual reports of three public limited companies in the OHADA zone that translate their financial statements into IFRS. The ranks of closeness and compliance index have been used to analyse data. Findings reveal a relatively high level of compliance with the accounting regulation by sampling limited liability companies. The results also give an indication of harmonisation in accounting practice of limited companies within member countries as they were found to be substantially consistent in compliance, especially in countries that have instituted the Statistics and Tax returns (or "DSF") as a reporting medium.
\end{abstract}

Keywords: Compliance, Divergence, Convergence, Harmonisation of accounting standards, OHADA Uniform Accounting Act, International Financial Reporting Standards

\section{Introduction}

Prior to the introduction of international accounting standards in 1973, countries reported business transactions using different national and zonal financial reporting standards, which were influenced by various factors, including sources of finance, cultural differences, legal systems, amongst others. Of course, the very existence of different reporting laws or standards resulted in incomparable financial reporting all over the world. This divergence in accounting reporting was detrimental to international business operators because informed judgements could not be taken by these global investors on incomparable financial information. The search for identical reporting (comparable figures), thus brought researchers on the podium for the quest for harmonisation. Harmonisation refers to the process of moving away from diversity to a position of harmony. The process of standardising accounting rules internationally, in order to gain comparability of financial information, requires a strong correlation between harmonised rules (de jure harmonisation) and harmonised practices of financial reporting (de facto harmonisation), (Tay and Parker, 1990; Van der Tas, 1988).

Today, the international accounting standards known as the International Financial Reporting Standards (IFRS) has been adopted in most parts of the world including some parts of Africa. According to a Deloitte and Touche 2009 survey, a total of 131 countries are currently using the IFRS. The approval of the European Union to use IFRS within its territories should have triggered its adoption to most former African colonies as it is known that most European countries (especially France) transfer technologies to their former colonies. This is, however, not the case with the 17 French-speaking African countries that constitute the Organisation for the Harmonisation of Business Laws in Africa. 


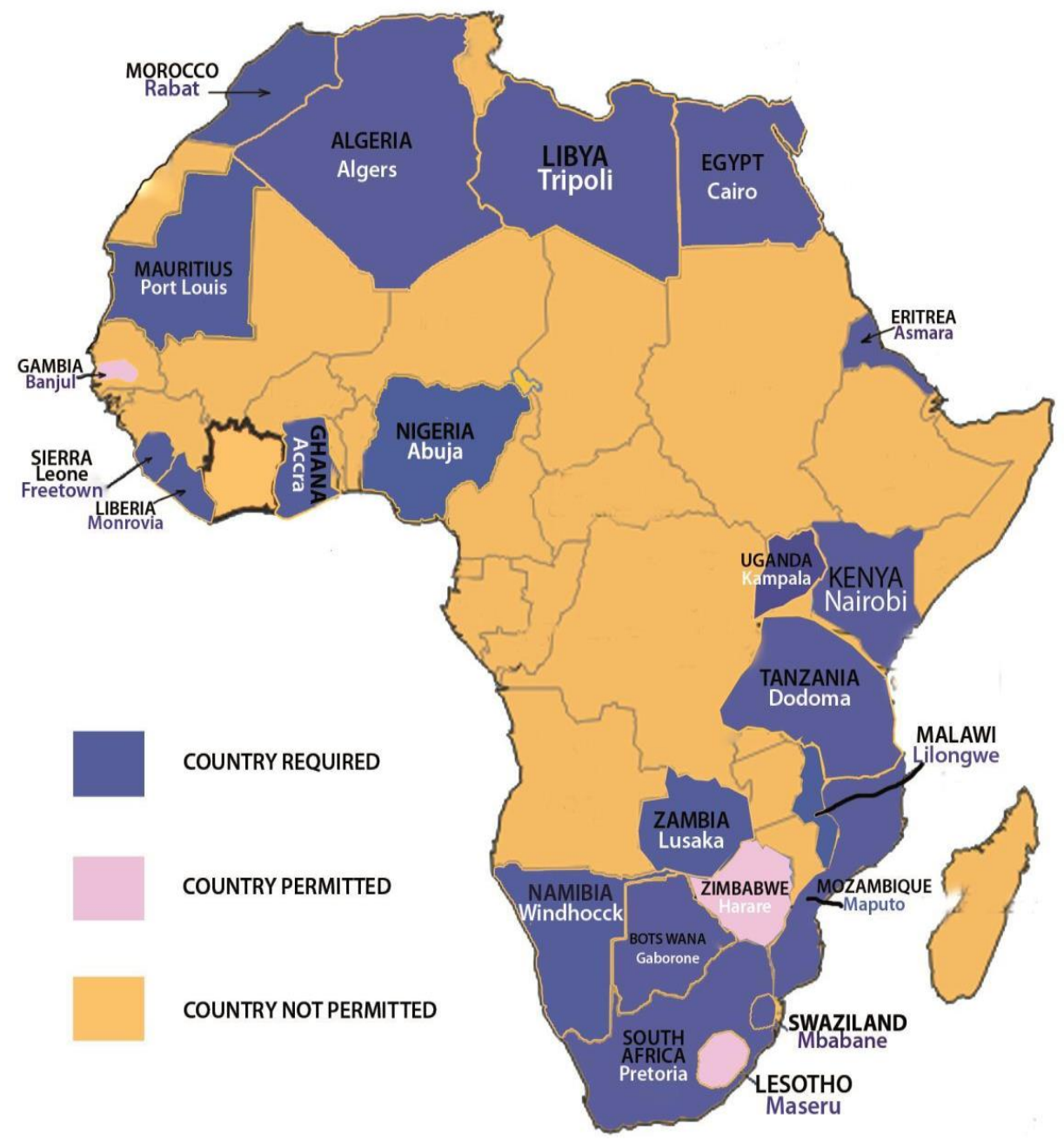

Figure 1. Map of African Countries Indicating Use of IFRS

Source: Author, 2016

The above figure depicts the level of use of IFRS within the African continent. As it portrays, all countries in blue have converged, or adopted and mandated the use of IFRS. It is also evident that IFRS comes with the development of stock markets as most countries that mandate the use of IFRS have stock markets. But, the OHADA member countries (OHADA zone) have not year adopted IFRS despite their desire and intention, and especially their relationship with their former colonial master - France.

The OHADA Uniform Accounting Act (OHADA UAA) was developed to solve the pressures of globalisation and to handle some of the lapses of the former accounting system known as "Organization Commune Des Etats Africain Malgaches et Mauriciens" (OCAM). The finance Ministers of member states identified the need to harmonise financial reporting standards and practices within French-speaking Africa in order to be up to date with global standards and also to increase the chances of attracting foreign direct investment (FDI) but this intention may not have been met as the global standards are not yet in use within this zone.

The harmonisation of domestic standards is important to developing countries, especially those in the OHADA zone. In order to develop their economies and capital markets, developing countries depend heavily on Foreign Direct Investments (FDI). The accounting standards used in companies within developing countries are greatly associated with FDI and play a vital role for developing countries to obtain funds from international investors. Therefore, the admissibility and use of these financial statements greatly depend on their reliability, which also depends on the set of standards on which these financial statements have been produced.

One of the best practices which allow countries to access foreign markets and helps them to become more integrated into the global economy is the act of harmonising business standards (Riasi \& Amiri Aghdaie, 2013). Harmonisation 
of financial reporting standards and accounting policies are among the most important types of harmonisation practices (Riasi, 2015; Riasi \& Amiri Aghdaie, 2013).There has been a remarkable effort in the harmonisation process of accounting policies and practices worldwide. Standardisation is imperative for setting benchmarks for measurement and reporting, especially among multinational companies that not only deal with home countries but also with other local governments where a branch or subsidiary is based. Users of financial statements such as the board of directors, investors, government and trade associations, all require a standard format for reporting financial statements since differences would result in wrong comprehension, interpretations and, consequently, wrong decisions pertaining to investment and management.

Harmonisation, from a de jure perspective, was aimed at when the OHADA Uniform Accounting Act (OHADA UAA) was streamlined with the International Financial Reporting Standards (IFRS) in 2000. Some researchers have measured and continue to measure the level of attainment. Harmonisation, from a de facto perspective, has met little assessment. We, therefore, wish to check that harmonisation, from a practical standpoint, has been achieved by assessing compliance with OHADA UAA by limited Liability Companies of member states.

\subsection{Problem Statement}

There has been a remarkable effort in the harmonisation process of accounting policies and practices worldwide. Some developing countries, grouped into regional blocks, have not only harmonised their accounting standards but have also adopted the International Accounting Standards and the World Bank has established programs to assist its member countries in implementing the international accounting and auditing standards through its reports on the Observance of Standards and Codes (ROSC) initiative. However, instead of adopting the International Financial Reporting Standards (IFRSs), 17 French-speaking African countries under the OHADA treaty have modified the OCAM Accounting system by only incorporating some of the IFRSs into what it now calls OHADA UAA (or OHADA GAAP) and it has not been determined if this is a successful way of harmonising their domestic standards with the rest of the world. Besides, it is equally not known if firms that use the OHADA UAA have a harmonised reporting practice.

This research thus seeks to analyse the state of harmonisation of practice of companies within OHADA by examining the following research questions:

1. To what extent do firms within the OHADA zone comply with the requirements of OHADA UAA?

2. Has compliance improved over time?

\subsection{Literature Review}

Van der Tas (1988) classified harmonisation into two classes namely, formal and material (or spontaneous harmonisation). Formal harmonisation is the harmonisation of standards, laws, or regulations. Material and spontaneous harmonisation is the harmonisation of accounting practices. "... an increase in the degree of comparability means that more companies in the same circumstances apply the same accounting method to an event or give additional information in such a way that the financial reports of more companies can be made comparable" (Van der Tas, 1988).

In the context of this study, harmonisation means both the harmonisation of laws and the harmonisation of practice. We see both as one and complementary but also as sequential. The harmonisation of laws or regulations will come before the harmonisation of practice as practice is based on the rules but harmonisation is not complete unless both are present, (see figure 2 below).

De facto or harmonisation of practice is the same as compliance with regulation, which is preceded by the de jure harmonisation. To have the accounting practice within member states of OHADA to be uniform, first the regulation has to be harmonised (de jure). This has already been achieved by 17 member states signing to the OHADA treaty. However, the ultimate is to make sure that the harmonised law is interpreted and used in the same way (harmonisation of practice or de facto harmonisation).The concept and relationship of harmonisation are illustrated below: 


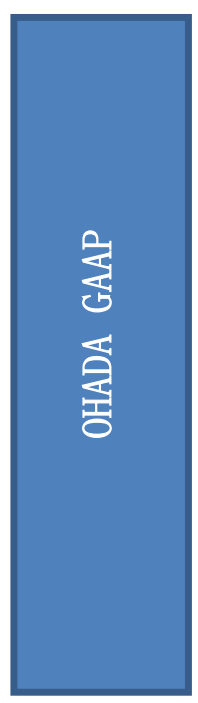

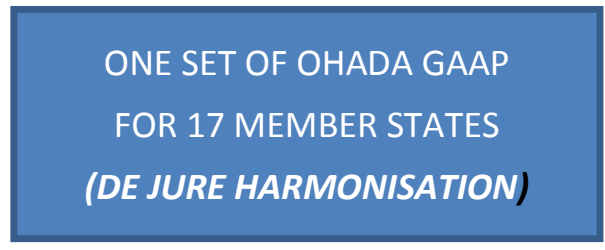

FORMAL HARMONISATION

OF DISCLOSURE

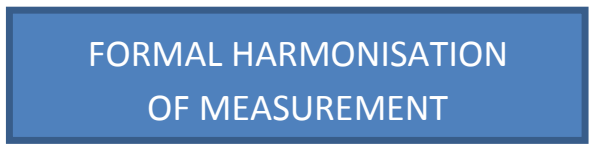

MATERIAL HARMONISATION

กF nISrI NSI IRF

PRACTICE CHOICES OF

COMPANIES IN DIFFERENT

MEMBER STATES
MATERIAL HARMONISATION

OF MEASUREMENT

Figure 2. Conceptualising Harmonisation of OHADA Uniform Accounting Act

Van der Tas (1988), used words like "comparability" and "harmony" as synonyms to de facto harmonisation. The concept of de facto harmonisation exist when there is an increase in the comparability of financial statements between two or more companies that use the same set of accounting standards. Companies in the same country within the same OHADA zone may or may not have identical reporting despite the use of the same sets of standards. The result may even be more stimulating on a country by country check.

Street and Gray (1999) evaluated selected listed U.S. firms' annual reports to observe whether these firms' accounting practices are in compliance with the IFRS. The 1996 annual reports of 38 U.S. companies listed in the 1995 Business Week Global 1,000 were examined. The study indicated that, in practice, the sample companies were, in essence, complying with the IFRS in many respects, notably IFRS 2, 16, 18, 19, and 23. There were some exceptions as a result of differences between the IFRS and U.S. GAAP. Where compliance was observed, it was due to consistency between IFRS and U.S. GAAP, rather than voluntary compliance. They concluded that the existence of differences in practice is not impossible even though there are still some significant issues to be identified and resolved. This brings us to the thought that even if compliance may only be attained to a certain extent, there is bound to be uniqueness in the application by individual companies in their application of the harmonised OHADA UAA.

Street and Gray (2001) examined the 1981 and 1999 annual reports of a worldwide sample of companies that use the IFRS. The purpose of the study was to explore the extent of non-compliance, and most importantly, to provide information about the factors associated with non-compliance. The sample included 279 companies worldwide. The major findings revealed different levels of compliance across countries and the factors that are associated with the level of compliance. Compliance was inclined to be significantly greater for companies that were based in China and Switzerland while lower for companies based in France, Germany, and other Western European countries. It is apparent that firms with similar situation and culture may employ similar fashion in reporting under the same standards. Although they are all French-speaking, companies within the Central African OHADA block may have more harmonised reporting amongst themselves when compared with companies from the West African block. Therefore, there is the chance of a wider divergence amongst companies outside one block than amongst companies within the same block.

In a similar study, Dunn (2002) investigated the extent of compliance with IFRS revised in a 1989 Comparability Project. They examined the 1996 annual reports of 49 major firms from twelve countries. The focus of compliance was on both measurement and disclosure issues. The study concluded that in all, the degree of compliance by companies produced mixed results for companies claiming to comply with the IFRS. Among the 49 firms investigated, only 4 were from developing countries (one from Hong Kong, one from Malaysia, and two from South 
Africa), while 45 were from developed countries - such a study was imbalanced and very little could be learned about developing countries, especially Africa. This imbalance puts the current study in place.

An attempt on the implementation of the IFRS in Africa was a study by Chamisa (2000) who investigated listed Zimbabwe firms' annual reports to find out if firms voluntarily complied with IFRS. Four published annual reports (one each for 1975, 1980, 1985 and 1990) were collected for 40 listed Zimbabwean firms. These annual reports were studied for compliance with the 46 disclosure and measurement requirements of IFRS 1 to IFRS 22. The study concluded that listed Zimbabwean firms appeared to voluntarily and significantly comply with certain but not all provisions that are required by IFRS but not required by the Zimbabwean Companies Act. This finding indicated that the IFRS had a significant impact on the accounting practices of listed Zimbabwean firms. However, the study's conclusion was based on the author's judgment and was not supported by statistical tests. For more than half of the requirements evaluated in the study, the compliance rate was below $50 \%$ and the author did not explain why firms did not voluntarily comply with these standards and whether the non-compliance was significant. Though within Africa, the study concentrated on one country thereby not giving a good picture about harmonisation of Africa's accounting standards with that of the IFRS.

In the same vein, Glaum and Street (2003) examined companies listed on the German securities Market to see their level of compliance with both the IFRS and the United States of America Generally Accepted Accounting Practice (US GAAP). They examined samples of 100 each for firms that apply the IFRS and GAAP. Based on the 2000 annual report of the sampled firms, they found that the compliance level of these firms ranges from $41.6 \%$ to $100 \%$ with an average range of $83.7 \%$. Companies that apply the IFRS had a lower average level of compliance than those that apply the US GAAP. This study, however, does not measure whether compliance improve over time as it was limited to one year data only.

A closer study is that of Bradshaw and Miller (2008) who consider whether harmonising standards harmonises accounting practices and can encourage compliance and implementation. They searched evidence for this in a sample of non-US firms that adopt US GAAP. The firms do adopt practices that are closer to those of US firms, though without fully converging to US GAAP. But, the study failed to disclose whether comparable reporting exists amongst firms that use the US GAAP as is the case of the current study.

Following the institution of the new accounting law in Cameroon, Fortin and Dicko (2007) carried out a study to compare the impact of the presentation and content differences that exist between the previous accounting law (OCAM) and the new one (OHADA UAA) on bankers judgements and decisions. Using a sample of 8 banks of the then 11 banks in Cameroon, the researchers found a difference in the banks judgements in the area of operating income, net income, cash flow, leverage, liquidity and the ability to raise capital, but did not reveal any difference in most areas of fundamental bank judgement and decisions, such as risk trend and rating, loan decision and risk premium (or interest rate to charge). This research proves that the change in accounting law (de jure), did not result in a change in practice (de facto) as the bankers could have a similar perception of the banking environment. In addition, the change in the accounting law did not improve the users' perception of the banking environment over time. It is important to note here that this study was based on the Central African Banking Commission's (COBAC) accounting law and not the OHADA UAA as in the current study. It is worth noting that the COBAC Accounting Law gets its roots from by the OHADA UAA. It is the OHADA UAA designed for the banking sector in order to take care of its particularities.

After the Francophone west and central Africa countries opened their economies by abolishing the traditional OCAM in favour of the modern OHADA, which is seen as having some features of IFRS, Avelé and Degos (2014), in a very simple comparative study, noted that there is still a great extent of divergence between OHADA UAA and IFRS although the ultimate motivation for its implementation was to make Francophone Africa have a more competitive financial reporting standards that would attract investors. The authors urge for improvement of the current OHADA law in order to be more convergent with the IFRS.

Peng, et al (2008) observed that the general compliance and harmonisation of standards by companies is difficult because of the institutional (cultural, legal, tax) differences among countries and the incentives those differences create amongst the preparers of financial reports. The influence of culture has been observed to have great influence on harmonisation in countries like Canada that has three different cultures namely; Anglo-Saxon culture, French-speaking culture, and Native American culture, and Cameroon having Francophone and Anglophone cultures are exposed to the difficulties of cultural differences in the use of the same regulation.

Some researchers have looked at compliance from the point of environmental factors surrounding the reporting entity. Jenkins, et al (2008) argue for consideration of culture and governance within accounting firms, suggesting further 
research findings in the area of culture as a cause of non-compliance. Their paper implies that part of the institutional setting which should also be considered, are the auditing and accounting firms who will oversee firms' accounts, and on whose work the supervisors and public also rely. There are great cultural differences in other countries in the world that may affect harmonisation due to wrong interpretation. Africa, India, and Iraq, for example, have totally different cultures. Cameroon, to be precise, does not eliminate the effect of language differences on the interpretation of international standards. Although cultures may eventually bond from engaging in increasingly frequent international business transactions, language differences will remain as a hindrance to the consistent use of international reporting standards. In Cameroon in particular, the issue of language difference makes the interpretation of the OHADA UAA difficult to the Anglophone and, consequently, difficult to achieve uniformity if the practice were compared with those of the francophone - this is an important area for future research.

The question of differences in culture and way of life can be echoed by the difference that may arise between regional and national laws and how this will affect the reporting decision of players within the confines of these conflicting laws. In Cameroon, for example, the General Tax Code conflicts with the OHADA UAA in the area of the deadline for filing company accounts and company tax returns. While a company files its tax returns latest 15 th March of the following year (article 18 of the General Tax Code), the latest date for filing annual accounts by the same companies is 30th April (article 23 of the OHADA UAA). According to François-Xavier Mayegle (2014), the very existence of this difference obstructs harmonisation of the practice of accounting within OHADA member countries, thereby bringing the Francophone Africa many steps backward in the process of harmonisation.

\subsection{Hypotheses}

To evaluate significant compliance with OHADA Uniform Accounting Act by companies in member countries and whether compliance has improved over time the following hypotheses are proposed:

H1: Public-Limited-Companies in OHADA member countries comply with the OHADA Uniform Accounting Act.

H2: Public-Limited-Companies' compliance with OHADA Uniform Act improved from 2008 to 2009

\section{Methodology}

\subsection{Data}

The main source of data used in this study is secondary data obtained from financial statements published in the annual reports of the three sample companies selected for this study namely: SIFCA SA, Metafrique Cameroon Sarl, and Kosan Crisplant Cameroon SA. The secondary data used in this study includes the Financial Statements and Reasonable Assurance of non-inclusion of material misstatements approved by independent auditors and usually published in the Companies' Annual Reports websites.

The specific reasons for the choice of the companies referred to above is the availability of annual reports and the willingness of reports preparers to provide certain explanations and clarifications when the need arose. It is also worth emphasising these are the few companies, within the scope of this study, that prepare their financial statements in both the OHADA UAA and the IFRS as such they are suitable for this study since harmonisation will be described from this perspective.

The choice of Cameroon and Ivory Coast is simply due to the fact that they are the only two countries in the OHADA zone with Stock Exchange Markets (SEM). Thus, it can confidently be said that Cameroon and Ivory Coast are the 'melting pots' in the OHADA zone, where all the economic and financial transactions of the zone are represented, considering that the financial reports are mainly used by stock markets. It is for these stock markets that comparability is being studied as companies without the right numbers may not be quoted. It is essential bearing in mind that the locale of this study is based on the assumption that the findings from the sample shall be generalised for the entire OHADA zone.

\subsection{Instrument}

A checklist instrument has been developed on accounting measurement items used by each sampled firm. All companies are supposed to be reporting under these items. A total of 10 measurement items are selected and each firm's reporting choice is matched with the standard, and ranked.

\subsection{Compliance Index}

This is used to analyse a firm's compliance with OHADA UAA. It is used to measure the degree of compliance at a national level. The number of companies selecting the same accounting choice is divided by the total number of companies in the sample to obtain the relative frequency of the same accounting method. A value of one indicates 
full compliance and a value within this range is an indication of non-compliance at various degrees - the higher the distance from one, the lower the degree of compliance. The compliance index is calculated for each firm in the sample. If a firm reported an item in accordance with the respective standard, then the item will be scored one. Non-compliance should receive a score of zero. If the item is not relevant to that company, the item is not included. A firm's compliance index is calculated by averaging compliance scores. The index is calculated for each firm and for each regulation across the two years under consideration to observe the trend in the harmonisation process. The degree of compliance of public limited companies to the OHADA UAA has either improved or not and with the use of the Compliance index in this study we shall be able to detect what is happening to de facto harmonisation at the national level.

\section{Results and Discussion}

As the research seeks to determine if compliance exists amongst public companies reporting using OHADA UAA, and whether time is a determinant of compliance, the compliance index has been used. Table 1 below gives a description of the measurement items based on OHADA UAA for the three companies under study. Companies used in the study include SIFCA SA, Kosan Crisplant Cameroon, and Metafrique. These companies' annual reports of 2008 and 2009 are used to find out if the practice is harmonised, as they all use the same accounting standards (OHADA UAA).

Table 1. Sample Firms Compliance with OHADA UAA

\begin{tabular}{|c|c|c|c|c|c|}
\hline ITEM & TOPIC & OHADA DESCRIPTION & SIFCA SA & KOSAN CRISPLANT & METAFRIQUE \\
\hline 1 & $\begin{array}{l}\text { Determination of cost } \\
\text { of goods sold }\end{array}$ & Measured using FIFO or ACM & Measured using ACM & Measured using ACM & Measured using ACM \\
\hline 2 & $\begin{array}{l}\text { Determination of } \\
\text { ending inventory }\end{array}$ & $\mathrm{LCM}$ is used & $\begin{array}{l}\text { Uses average weighted } \\
\text { method }\end{array}$ & $\begin{array}{l}\text { Uses average weighted } \\
\text { method }\end{array}$ & $\begin{array}{l}\text { Stated at the lower of cost and net } \\
\text { Realisable value }\end{array}$ \\
\hline 3 & $\begin{array}{l}\text { Recognition of tax } \\
\text { expense/income }\end{array}$ & $\begin{array}{l}\text { Recognised as income or } \\
\text { expense and included in the net } \\
\text { profit or loss }\end{array}$ & $\begin{array}{l}\text { Recognised as income or } \\
\text { expense and included in the } \\
\text { net profit or loss }\end{array}$ & $\begin{array}{l}\text { Recognised as income or loss } \\
\text { and included in the net profit } \\
\text { or loss }\end{array}$ & $\begin{array}{l}\text { Recognised as income or loss and } \\
\text { included in the net } \\
\text { profit or loss }\end{array}$ \\
\hline 4 & $\begin{array}{l}\text { Determination of } \\
\text { depreciation method } \\
\text { of PP\&E }\end{array}$ & $\begin{array}{l}\text { Allocates the asset's cost over } \\
\text { its useful life according to a } \\
\text { predetermined plan }\end{array}$ & $\begin{array}{l}\text { Allocates the asset's cost } \\
\text { over its useful life } \\
\text { according to a } \\
\text { predetermined plan }\end{array}$ & $\begin{array}{l}\text { Allocates the asset's cost over } \\
\text { its useful life according to a } \\
\text { predetermined plan }\end{array}$ & $\begin{array}{l}\text { Allocates the asset's cost over its } \\
\text { useful life according to } \\
\text { Predetermined plan }\end{array}$ \\
\hline 5 & $\begin{array}{l}\text { Measurement of } \\
\text { goodwill }\end{array}$ & $\begin{array}{l}\text { Recognised as an asset an } \\
\text { adjustment to shareholders' } \\
\text { equity }\end{array}$ & $\begin{array}{l}\text { Recognised as an asset an } \\
\text { adjustment to shareholders' } \\
\text { equity }\end{array}$ & $\begin{array}{l}\text { Recognised as an asset and } \\
\text { expensed to profit and loss } \\
\text { account }\end{array}$ & $\begin{array}{l}\text { Recognised as an asset and expensed } \\
\text { to profit and loss account }\end{array}$ \\
\hline 6 & $\begin{array}{l}\text { Measurement of } \\
\text { provisions }\end{array}$ & $\begin{array}{l}\text { The decrease is subtracted from } \\
\text { the asset }\end{array}$ & $\begin{array}{l}\text { Decrease is subtracted from } \\
\text { the asset }\end{array}$ & $\begin{array}{l}\text { A provision is recognised as a } \\
\text { liability and expensed } \\
\text { periodically }\end{array}$ & Decrease is subtracted from the asset \\
\hline 7 & $\begin{array}{l}\text { Criteria for } \\
\text { determination of bad } \\
\text { debt allowable }\end{array}$ & Determined by company & Determined by company & Determined by company & Determined by company \\
\hline 8 & Operating expenses & $\begin{array}{l}\text { Accounted by nature and } \\
\text { charged to expenses }\end{array}$ & $\begin{array}{l}\text { Accounted by nature and } \\
\text { charged to expenses }\end{array}$ & $\begin{array}{l}\text { Accounted by nature and } \\
\text { charged to expenses }\end{array}$ & $\begin{array}{l}\text { Accounted by nature and charged to } \\
\text { expenses }\end{array}$ \\
\hline 9 & $\begin{array}{l}\text { Operating lease } \\
\text { income/expense }\end{array}$ & Recorded as expense/income & $\begin{array}{l}\text { Recorded as } \\
\text { expense/income }\end{array}$ & Recorded as expense/income & Recorded as expense /income \\
\hline 10 & $\begin{array}{l}\text { Initial recognition of } \\
\text { foreign currency }\end{array}$ & $\begin{array}{l}\text { Items acquired in foreign } \\
\text { currencies in the books in the } \\
\text { currency unit which is legal } \\
\text { tender in the country after } \\
\text { conversion of their cost in } \\
\text { foreign currency at the currency } \\
\text { exchange rate applicable on the } \\
\text { date of acquisition }\end{array}$ & $\begin{array}{l}\text { Items acquired in foreign } \\
\text { currencies in the books in } \\
\text { the currency unit which is } \\
\text { legal tender in the country } \\
\text { after conversion of their } \\
\text { cost in foreign currency } \\
\text { exchange rate applicable on } \\
\text { the date of acquisition }\end{array}$ & $\begin{array}{l}\text { Items acquired in foreign } \\
\text { currencies in the books in the } \\
\text { currency unit which is legal } \\
\text { tender in the country after } \\
\text { conversion of their cost in } \\
\text { foreign currency exchange } \\
\text { rate applicable on the date of } \\
\text { acquisition }\end{array}$ & $\begin{array}{l}\text { Items acquired in foreign currencies } \\
\text { in the books in the currency unit } \\
\text { which is legal tender in the country } \\
\text { after conversion of their cost in } \\
\text { foreign currency rate applicable on } \\
\text { the date of acquisition. }\end{array}$ \\
\hline
\end{tabular}

Source: Author (2016)

From Table 1 above, the ranking can be done to find out the number of measurement items with which SIFCA SA, Kosan Crisplant Cameroon SA and Metafrique sarl do not comply with the OHADA UAA for each year of reporting. 
Table 2. Ranking of Compliance with OHADA

\begin{tabular}{|c|c|c|c|c|c|c|c|}
\hline & & \multicolumn{2}{|c|}{$\begin{array}{l}\text { SIFCA SA } \\
\text { ranking }\end{array}$} & \multicolumn{2}{|c|}{$\begin{array}{c}\text { KOSAN } \\
\text { CRISPLANT }\end{array}$} & \multicolumn{2}{|c|}{$\begin{array}{l}\text { METAFRIQUE } \\
\text { SARL }\end{array}$} \\
\hline & & 2008 & 2009 & 2008 & 2009 & 2008 & 2009 \\
\hline 1 & Determination of cost of goods sold & 1 & 1 & 1 & 1 & 1 & 1 \\
\hline 2 & Determination of ending inventory & 0 & 0 & 0 & 0 & 0 & 0 \\
\hline 3 & Recognition of tax expense/income & 1 & 1 & 1 & 1 & 1 & 1 \\
\hline 4 & $\begin{array}{l}\text { Determination of depreciation } \\
\text { method PP \&E }\end{array}$ & 1 & 1 & 1 & 1 & 1 & 1 \\
\hline 5 & Measurement of goodwill & 1 & 1 & 1 & 0 & 1 & 1 \\
\hline 6 & Measurement of provisions & 0 & 0 & 0 & 0 & 1 & 1 \\
\hline 7 & $\begin{array}{l}\text { Criteria for determination of bad } \\
\text { debt allowable }\end{array}$ & 1 & 1 & 1 & 1 & 1 & 1 \\
\hline 8 & Operating expenses & 1 & 1 & 1 & 1 & 1 & 1 \\
\hline 9 & Operating lease incomes/expenses & 1 & 1 & 1 & 1 & 1 & 1 \\
\hline 10 & $\begin{array}{l}\text { Initial recognition of foreign } \\
\text { currency }\end{array}$ & 1 & 1 & 1 & 1 & 1 & 1 \\
\hline
\end{tabular}

Source: Author (2016)

Table 3. Compliance Index for Sample Companies

\begin{tabular}{lccc}
\hline & 2008 index & 2009 index & Mean compliance index \\
\hline SIFCA SA & 0.8 & 0.8 & 0.8 \\
KOSAN & 0.8 & 0.9 & 0.85 \\
METAFRIQUE SARL & 0.9 & 0.9 & 0.9 \\
\hline
\end{tabular}

Source: Author (2016)

From table 3 of compliance indices, it can be seen that SIFCA SA complies with $80 \%$ of the 10 selected measurement items for the two years meaning that the methods of measurement and disclosure used for 2008 were the same used for 2009. As for Kosan Crisplant Cameroon SA, the compliance index was 0.8 in 2008 but increased to 0.9 in 2009 while Metafrique Sarl has a 0.9 compliance consistently for two years.

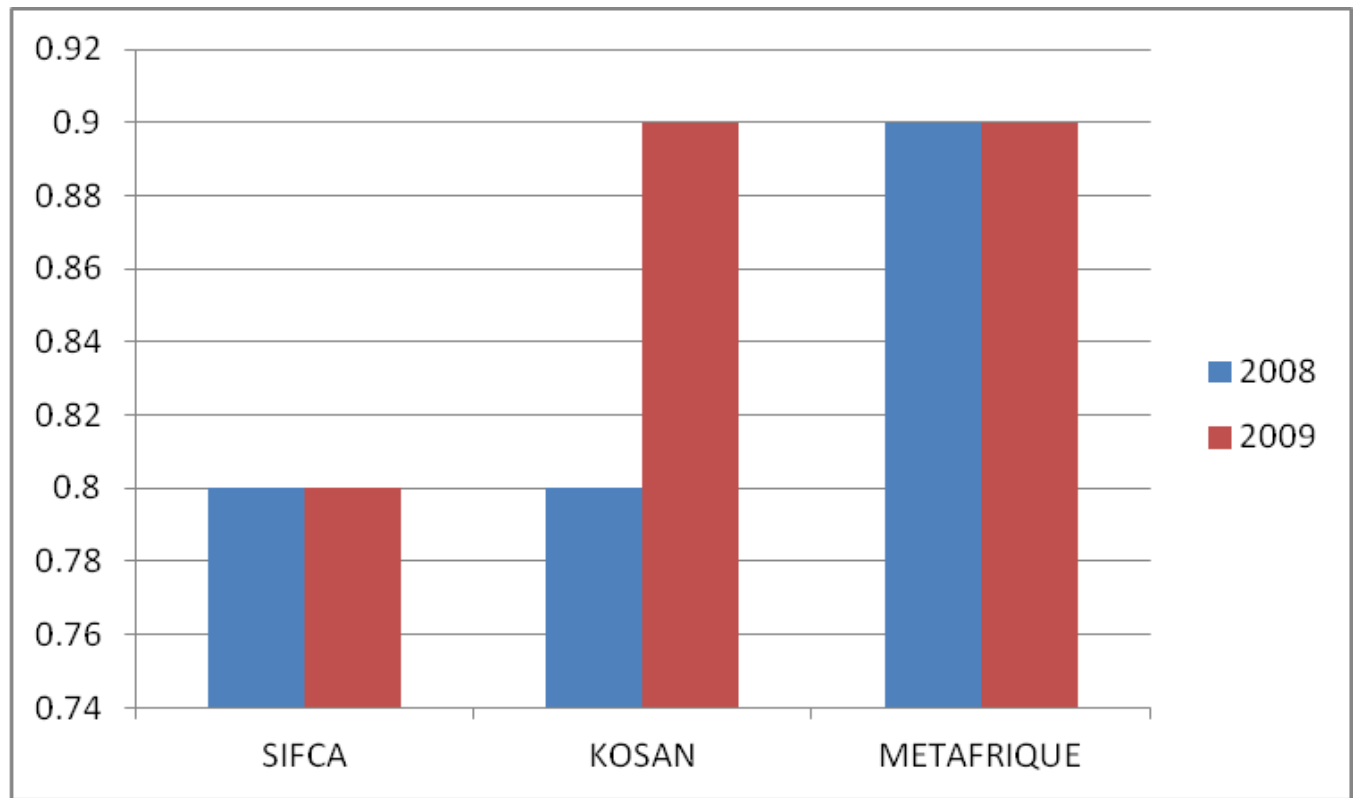

Figure 2. Histogram of Compliance Indices for Sample Companies Over Two Years

Source: Author (2016) 


\subsection{Tests of Hypotheses $\mathrm{H} 1$ and $\mathrm{H} 2$}

H1: Public Limited Companies in OHADA member countries significantly comply with OHADA Uniform Accounting Act.

H1 is estimated by calculating the compliance index for each company for 2008 and 2009 based on their annual reports for the two years. If the annual compliance index is not significantly different from one, H1 is supported because it will mean that there is a significant level of compliance of practice with the standard. A compliance index of 0.8 for SIFCA indicates that SIFCA complies with 8 out of the 10 selected measurement items. Kosan and Metafrique have a compliance index of 0.9 for the year 2009 which implies that they are in compliance with 9 out of the 10 measurement items selected for the test which is not significantly different from one. Hence, H1 is supported.

\section{H2: Public Limited Companies' compliance with OHADA UAA has improved over Time}

$\mathrm{H} 2$ was estimated by calculating the compliance indices for the 3 (SIFCA, KOSAN CRISPLANT and METAFRIQUE Sarl) companies for the two years based on their annual reports which are examined to determine if they are significantly different from the expected value of one. $\mathrm{H} 2$ is tested and supported if the mean compliance index is not significantly different from the expected value of one.

The chi-square test is used to test hypothesis H2. It is useful to detect the divergence of an observed value from its expected value for a single group. It is used to test for goodness of an observed distribution to a theoretical one. For example, the expected mean compliance index for SIFCA is $100 \%$ but the observed value is $80 \%$. If the test statistics is smaller than the critical value, then the null hypothesis that the observed value is not significantly different from the expected is supported. As shown in the table below, $\mathrm{H} 2$ is supported at $5 \%$ level of significance.

\begin{tabular}{lcc}
\hline SIFCA & CPL & $80 \%$ \\
Test Statistics & & $85 \%$ \\
\hline Kosan & CPL & $90 \%$ \\
7.825 & CPL & \\
Metafrique & & \\
df $=2$ & & \\
Significant at $\mathrm{p}=0,05$ &
\end{tabular}

SIFCA CPL= mean compliance index for SIFCA

Kosan $C P L=$ mean compliance index for kosan

Metafrique $C P L=$ mean compliance index for metafrique

$d f=$ degree of freedom

Since chi-square exceeds the critical value for 0.05 level probability levels (5.991), means companies in the OHADA zone comply with the OHADA Uniform Accounting Act. Hence H2 is supported since there is clear evidence that there is a significant increase in the compliance level of the firms with the standards over time (from good in 2008 to better in 2009).

Table Summary of Hypotheses Test Results

\begin{tabular}{cllll}
\hline & Hypothesis & Measurement method & Test method & Test Results \\
\hline H1 & $\begin{array}{l}\text { Public Limited Companies in OHADA } \\
\text { Zone Are Significantly In Compliance }\end{array}$ & Compliance Index & $\begin{array}{l}\text { Chi-square test } \\
\text { for symmetry }\end{array}$ & Supported \\
& With OHADA UAA & & \\
H2 & $\begin{array}{l}\text { The Degree of Public Limited Companies’ } \\
\text { Compliance with OHADA UAA Has } \\
\text { Improved Over Time }\end{array}$ & Compliance Index & $\begin{array}{l}\text { Compliance - } \\
\text { Index }\end{array}$ & Supported \\
\end{tabular}

\section{Conclusion}

Considering the findings and results presented in this study to examine the level of compliance of the OHADA UAA from a de facto perspective, and by testing the set hypotheses of the study, the research provides evidence that firms in the OHADA zone significantly comply with the OHADA Uniform Accounting Act, within 2008 and 2009. This 
result has been triggered by Kosan Crisplant whose compliance level improved from 0.8 in 2008 to 0.9 making the level of compliance with standards increase from 2008 to 2009, which is evidence that the older the accounting standard the higher the compliance. This increase in compliance with the standard is as a result of an increase in the understanding of the standards by users and a better interpretation. Therefore with time, people get more informed to a set of laws than when these laws were introduced. However, due to limited information and the small sample of measurement items considered, in addition to the fact that it considers only two years, this conclusion cannot be evidently generalised. But, the study gives an indication that a continuous improvement of de jure harmonisation (by reshaping OCAM Plan to OHADA UAA) will improve de facto harmonisation as we could see improvement in harmonisation when member states move from OCAM to OHADA UAA.

There has been a big change between 1975 and 2011 since the introduction of the International Financial Reporting Standards in terms of globalisation of capital markets. Investors can now seek investment opportunities all over the world because of the use of one accounting language. Africa needs to attract these investments. Companies seek capital at the lowest price anywhere but accounting differences reduce understanding and obscure comparisons that investors want to make an informed decision. The OHADA UAA is just one way to address this need. The use of one set of standards, especially a high quality global financial reporting standards like the IFRS, even within the OHADA member states, will benefit investors, lenders, and the African continent as a whole.

\section{Acknowledgement}

The author would like to thank an anonymous reviewer of this paper for providing insightful comments and direction.

\section{References}

Avelé, D. \& Degos, J-G. (2014). 'Standardisation of international accounting: harmonisation between OHADA and IASB (IFRS) reference frameworks', African J. Accounting, Auditing and Finance, 3(1), 27-47.http://dx.doi.org/10.1504/AJAAF.2014.065176

Bradshaw, M.T., \& Miller. G.S.(2008). Will Harmonising Accounting Standards Really Harmonise Accounting? Evidence from Non-US Firms Adopting U.S. GAAP. Journal of Accounting, Auditing and Finance, 23(2).

Chamisa, E. E. (2000). The Relevance and Observance of the IASC Standards in Developing Countries and the Particular Case of Zimbabwe. The International Journal of Accounting, 35(2), 267-286.http://dx.doi.org/10.1016/S0020-7063(00)00049-2

Deloitte \& Touche. (2009). IFRS Survey Results 2009: Update on views and activities. Retrieved from www.iasplus.com/usa/0909 ifrssurvey.pdf

Dunn, P. (2002). International Accounting Standards. Journal of Accounting Literature.

François-Xavier Mayegle. (2014). OHADA Accounting System and Harmonization of Accounting Practice in Francophone Sub-Saharan Africa", International Journal of Business and Social Science, 5(10).

Glaum, M., \& Street, D.L. (2003). Compliance with the disclosure requirements of Germany's new market: IAS versus US GAAP. Journal of International Financial Management \& Accounting, 14(1), 64-100.http://dx.doi.org/10.1111/1467-646X.00090

Gray, S. J. (1980). The Impact of Adopting International Accounting Standards on the Harmonisation of Accounting Practices. International Journal of Accounting, 35(4), 471-493.

J. Gregory Jenkins, Donald R. Deis, Jean C. Bedard, \& Mary B. Curtis. (2008). Accounting Firm Culture and Governance: A Research Synthesis. Behavioral Research in Accounting: Spring, 20(1), 45-74.http://dx.doi.org/10.2308/bria.2008.20.1.45

Nobes, C., \& Roberts, A. (1998). Towards a Unifying Model of Systems of Law, Corporate Financing, Accounting and Corporate Governance. University of Reading, Series D, X(6), 1998/99.

OHADA UNIFORM ACT, Organizing and Harmonizing Undertakings' Accounting Systems In The Signatory States to The Treaty on The Harmonization Of Business Law In Africa, OHADA Official Journal No. $10-4$ th Year,http://www.juriscope.org/uploads/pdf/ohada/OHADA_en/comptable-gb.pdf, 2016

Peng, S., R.H. Tondkar, J.L. Smith, \& D. Harless. (2008). Does convergence of accounting standards lead to the convergence of accounting practices? The International Journal of Accounting, 43, 448-468.http://dx.doi.org/10.1016/j.intacc.2008.09.009 
Riasi, A., \& Amiri Aghdaie, S. F. (2013). Effects of a Hypothetical Iranian Accession to the World Trade Organization on Iran's Flower Industry. Consilience: The Journal of Sustainable Development, 10(1), 99-110. http://dx.doi.org/10.7916/D8HQ3ZK8

Riasi, A. (2015). Competitive Advantages of Shadow Banking Industry: An Analysis Using Porter Diamond Model. Business Management and Strategy, 6(2), 15-27. http://dx.doi.org/10.5296/bms.v6i2.8334

Street, D.L., \& Gray, S.J. (2001). Observance of International Accounting Standards: Factors Explaining Non-Compliance, ACCA Research Report No. 74.

Street, D.L., Gray, S.J. \& Bryant, S.M. (1999). Acceptance and Observance of International Accounting Standards: An Empirical Study of Companies Claiming to Comply with IASs'. The International Journal of Accounting, 34(1), 11-48.http://dx.doi.org/10.1016/S0020-7063(99)80002-8

Tay, J. S. \& Parker,R. H. (1990). Measuring International Harmonisation and Standardisation. Abacus 26(1), 7 1-88.http://dx.doi.org/10.1111/j.1467-6281.1990.tb00233.x

Van Der Tas, L. G.(1988). Measuring Harmonisation of Financial Reporting Practice. Accounting and Business Research, 18(70), 157- 169.http://dx.doi.org/10.1080/00014788.1988.9729361 